\title{
The coming and going of come and go Multi-verb directional motion constructions in Surinamese Javanese
}

\author{
SOPHIE VILLERIUS
}

\begin{abstract}
This article examines multi-verb directional motion constructions in Surinamese Javanese, a heritage language subject to structural influence from Dutch and Sranantongo. These are constructions which express "direction away" by means of a V2 lunga 'go away'. They are more frequent - and used with more different $\mathrm{V} 1 \mathrm{~s}$ - than in Indonesian Javanese, the baseline. The frequency change is a pattern change, a result of cross-linguistic transfer from Sranantongo, in which multi-verb constructions to express "direction away" are very frequent. The extension of the usage contexts to more V1s is a form of semantic extension, and it is the first stage in contact-induced grammaticalization. This is caused by the entrenchment of the schema motion verb + away, which exists in both Dutch and Sranantongo. The meaning of the constructions is also changing: whereas in Indonesian Javanese the directional element never refers to the causee alone, it frequently does in Surinamese Javanese. Finally, some preliminary observations are made with respect to the possible development of a parallel construction expressing "direction towards" with V2 teka 'come', modelled on the Sranantongo multi-verb constructions with V2 kon 'come'.

KEYWORDS

Javanese; Sranantongo; language contact; cross-linguistic influence; multi-verb constructions.
\end{abstract}

SOPHIE VILLERIUS graduated from the University of Amsterdam, where she obtained a BA in Religious Studies and a BA in French Language and Culture in 2011, and a Research MA in Linguistics in 2013. She started her PhD-project on Surinamese Javanese at Radboud University Nijmegen in 2013. For her research, she did fieldwork in Suriname and Indonesia. During the project, she was one of the Faces of Science of the KNAW (Royal Netherlands Academy of Arts and Sciences). This research resulted in the publication of the PhD-dissertation Development of Surinamese Javanese; Language contact and change in a multilingual context in 2018. Currently she is working as a software developer. Sophie Villerius can be reached at: sophievillerius@ gmail.com.

(C) 2021 Faculty of Humanities, Universitas Indonesia

SOPHIE VILLERIUS | DOI: 10.17510/wacana.v22i2.1037. 


\section{INTRODUCTION ${ }^{1}$}

Surinamese Javanese is a heritage language spoken in Suriname since the end of the nineteenth century. Its speakers are usually multilingual in Dutch and Sranantongo (an English-lexifier creole and the lingua franca of Suriname). In its corpus it is possible to encounter sentences such as the example in (1), used to describe an image depicting a dog chased by bees, trying to run from them (the "Frog story" (Mercer Mayer 1969)).

$$
\begin{aligned}
& \text { Asu-né mlayu lunga }{ }^{2} \\
& \text { dog-DEF run go } \\
& \text { 'The dog runs away.' (JVN-20140512-SJ-01-200-83M-frogstory) }
\end{aligned}
$$

In this example, the event of 'running away' is expressed by means of a multi-verb construction ${ }^{3}$ consisting of V1 mlayu 'run' and V2 lunga 'go'. For an Indonesian speaker of Javanese, this construction might sound a bit odd, although not strictly ungrammatical. However, the combination of the two verbs could be classified as somewhat redundant, since each of them separately carries the meaning of 'run away/flee'. Indonesian speakers would tend to produce a sentence as in (2), with only one of these verbs.

$$
\begin{aligned}
& \text { Asu-né mlayu, wedi tawon } \\
& \text { dog-DEF run scared bee } \\
& \text { 'The dog runs away, scared of the bees.' } \\
& \text { (JAV-201060405-IJ-36-C-51F-frogstory) }
\end{aligned}
$$

The difference between the Surinamese and Indonesian speakers lies in the fact that Surinamese speakers prefer to separate the manner of motion (mlayu 'run') from the path or direction of motion (lunga 'go') by using two verbs in a multi-verb construction, whereas Indonesian speakers use one verb to express both the manner and direction of motion (typology of motion from Leonard Talmy 1985). The particular combination used by Surinamese

${ }^{1}$ This article is a reworking of a chapter in my dissertation, Development of Surinamese Javanese (Villerius 2018), which can be downloaded at https://www.lotpublications.nl/ development-of-surinamese-javanese. The research presented in this dissertation was funded by a grant from the Netherlands Graduate School of Linguistics (LOT) through the Netherlands Organisation for Scientific Research (NWO) in the context of the project "Language - from cognition to communication" (NWO project number 022.004.015).

${ }^{2}$ Note on orthography: for Surinamese Javanese, I adhere to the official Surinamese Javanese orthography also used in the dictionary of Hein Vruggink (2001: xli). This orthography is largely similar to that of Indonesian Javanese, and includes the use of diacritics to distinguish the vowels /e/ <é> and $/ \varepsilon /<\mathrm{e}>$. The main difference between the standard Javanese orthography and Surinamese orthography is in the representation of $/ c /$, which is $\langle\mathrm{c}\rangle$ in the standard and $<$ ty $>$ in the Surinamese system.

${ }^{3}$ This type of construction is also often referred to as serial verb construction (SVC), for instance, in Caribbean Creole linguistics and elsewhere. However, since the definition of this term can differ from language family to language family, it might not be comparable across language families. Therefore, I prefer to use the more neutral term "multi-verb construction" here. I use $\mathrm{V} 1$ and V2 to refer to the first and second verb of a multi-verb construction, respectively. 
speakers becomes all the more striking when it is compared to descriptions of the same scene by Sranantongo speakers, one of the contact languages of Surinamese Javanese, as in (3).

\section{(3) A dagu lon gwe \\ DEF dog run go}

'The dog runs away.' (JVN-20170407-SJ-45-401-31F-frogstory-sr)

The question which this article seeks to answer is whether these two constructions in Sranantongo and Surinamese Javanese are related, and if there has been some form of cross-linguistic transfer from Sranantongo to Surinamese Javanese. Language change through contact is to be expected in the Surinamese Javanese speech community since the three languages, Javanese, Dutch, and Sranantongo, are in constant interaction. This contact takes place on the level of the community (multiple languages alongside each other and language attitudes) as well as on the level of individual speakers (frequent code-switching and borrowing). The situation of Surinamese Javanese has been classified as a case of language shift (Kofi Yakpo, Margot van den Berg, and Robert Borges 2015: 166) in which Dutch and Sranantongo are becoming increasingly dominant. Heritage speakers like the Surinamese Javanese, form a unique population to study the importance of factors such as the nature of linguistic input, incomplete acquisition, universal principles and direct transfer in the process of language change. Synchronically, language contact is visible through the presence of loan translations, code-switching, and borrowings, which can be observed fairly easily and directly. Diachronically, deeper grammatical changes can occur in the linguistic system of the heritage language, which might require a more in-depth study to spot. These changes can include re-analysis, consolidation, overgeneralization, reduction/loss, or simplification of linguistic structures (Yakpo, Van den Berg, and Borges 2015). This article seeks to examine the latter type of change because few studies have been done on this topic, especially in Indonesian linguistics. The nature of the diachronic language contact in Surinamese Javanese is also relevant here, since it has had a longer and more profound contact with Sranantongo than with Dutch and consequently might have undergone more structural influence from Sranantongo (Villerius 2018).

In order to answer the question of whether these constructions in Surinamese Javanese are related to those in Sranantongo, it is important to establish how widespread they are in Surinamese Javanese. Are there other types of motion multi-verb constructions related to Sranan constructions? Does the construction spread into possibilities with other V1s? By comparing the multi-verb construction expressing "direction away"4 found in Surinamese Javanese to similar cases in Sranantongo and Dutch, I propose that this is

${ }^{4}$ Other terms used in the literature for the grammatical phenomena of direction away/ towards are itive/ventive, or sys-locative/trans-locative. Since I do not focus on typology and morphology in this article, I shall use the theoretically neutral terms "direction away" and "direction towards", simply referring to the meaning of these constructions. 
more than a coincidence: the use of this construction has been influenced by transfer from Sranantongo and reinforced by the presence of a similar (particle verb) construction in Dutch.

One of the ways in which the construction could have been transferred from Sranantongo to Surinamese Javanese involves the notion of entrenchment. Entrenchment has been defined as "the degree to which the formation and activation of a cognitive unit is routinized and automated" (Hans-Jörg Schmid 2012: 119). The cognitive unit refers to a linguistic unit, be this a word or, in this case, a construction or linguistic schema. The level of entrenchment of a construction increases with higher frequency (not of the unit per se, but of the unit with that specific meaning) and recency, that is how shortly earlier or long ago it was last encountered. Entrenchment is an important factor in contactinduced change, since the structures which a speaker encounters in the contact language(s) will become more entrenched and subsequently have a higher probability of surfacing in the heritage language. It has been used to explain the preference for finite subordination in Dutch heritage speakers of Turkish (Pelin Onar Valk and Ad Backus 2013) and for progressive constructions in Dutch heritage speakers of Spanish (Pablo Irizarri van Suchtelen 2016).

In the analysis of motion events, the most influential typology is that by Talmy (1985), who first distinguishes the internal from the external components of motion events. The internal components are the basic elements Figure, Ground, Path, and Motion ("presence per se in the event of motion or location", either "move" or "be.at"). The external components express the Manner and/or the Cause of motion (for example, "run", "be pushed"). In this article, I make a distinction between motion events focusing on the Manner of motion (in which the subject of motion I is an agent), as in (4), versus motion events with Caused motion (in which the subject of motion the keg is an undergoer) as in (5), because as we shall see, these constructions behave slightly differently.

(4) Manner of motion (Talmy 1985: 63)

I ran/limped/jumped/stumbled/rushed/groped my way down the stairs.

(5) Caused motion (Talmy 1985: 63)

I pushed/threw/kicked the keg into the storeroom.

This article is structured as follows: Section 2 describes the specific methodology used in this article. Then, Section 3 presents the motion multiverb constructions which have been encountered in Indonesian Javanese. Section 4 gives an overview of the motion multi-verb constructions of Sranantongo and 5 gives the relevant motion constructions in Dutch. Section 6 presents the data from Surinamese Javanese and compares them to the Indonesian Javanese data. Section 7 discusses the results and Section 8 presents the conclusions. 


\section{Methodology AND CORPUS}

\subsection{Materials}

To explore the frequency and types of motion multi-verb constructions in Surinamese Javanese, I have made use of a corpus of audio speech recordings of four different languages: Surinamese Javanese, Indonesian Javanese, Sranantongo, and Surinamese Dutch. These recordings were collected during fieldwork sessions in 2014, 2015, and 2017, as part of my PhD research which resulted in the publication of Villerius (2018). In view of the small size of the corpora for Sranantongo and Surinamese Dutch collected in 2017, I also used data collected in Suriname in 2012 by Kofi Yakpo and Stanley Hanenberg for additional examples of certain constructions, as will be indicated in the relevant sections. These latter data were used only for qualitative comparison. All the examples in this article will be from my own corpora, unless otherwise stated.

\subsection{PARTICIPANTS}

The corpora of the different languages were of different sizes, specified in Table 1.

\begin{tabular}{lll} 
Language & Years collected & $\begin{array}{l}\text { Corpus size (approx. number of } \\
\text { words) }\end{array}$ \\
\hline Surinamese Javanese & $2014,2015,2017$ & 81,300 \\
Indonesian Javanese & 2016 & 82,400 \\
Sranantongo & 2017 & 7,500 \\
Surinamese Dutch & 2017 & 6,000
\end{tabular}

Table 1. Corpora used for the study of multi-verb motion constructions for Surinamese and Indonesian Javanese, Sranantongo, and Surinamese Dutch.

\section{Multi-VERB MOTION CONTRUCTIONS In INDONESIAN JAVANESE}

In order to examine possible effects of language contact on Surinamese Javanese, we should first establish to what extent these constructions are frequent and productive in Indonesian Javanese. If a difference in frequency between Surinamese and Indonesian Javanese is found, we shall examine the frequency of these constructions in the contact languages of Surinamese Javanese. This section identifies the different types of multi-verb constructions which are found in Indonesian Javanese to encode motion events. I also give an indication of how frequent/common the constructions are in the corpus. I use the division between Manner of motion and Caused motion, as explained in the introduction (Talmy 1985: 69).

\subsection{MANNER OF MOTION}

In the Indonesian Javanese corpus, there are several examples of multi-verb constructions in which the V1 is a manner of motion verb (that is, 'walk' or 'run') and the V2 expresses the direction of the movement (that is, 'go out' or 'go up'). See examples (6) and (7). 
(6) Lha kodhok sing ning njero toplès mau arep mlumpat metu EXCL frog REL LOC inside bottle DEM FUT jump go.out 'Then the frog which was inside the bottle just now is going to jump out.' (JAV-20160331-IJ-18-C-38F-frogstory)

(7) Ana bocah wadon mlayu medhun ing tangga

EXIST child female run go.down LOC stairs

'There is a girl running down the stairs.'

(JAV-20160331-IJ-40-C-23M-focuspictures)

These constructions are not frequent in the corpus; the only combinations found are the following: mlumpat metu 'jump go out', mlayu metu 'run go out', mlayu medhun 'run go down', mlayu munggah 'run go up'. All of these combinations are found just one single time in the corpus, with the exception of mlumpat metu which is found twice. This means a total occurrence of 0.06 times per 1,000 words.

There is one occurrence in the corpus of a multi-verb construction with V2 lunga, which is given in (8). However, I do not count this example as the same kind of multi-verb construction as (1) above, but rather as two separate predicates. This is because the intonation pattern is not the same as in one multi-verb construction (the speaker goes up on kabur 'gone', as at the end of a clause and then up again at lunga), and there is a slight but audible pause in between the two predicates.

\section{(8) Wis kabur, lunga}

PRF gone go

'(He) has already gone, away.' (JAV-20160331-IJ-18-C-38F-frogstory)

One other example of a construction with lunga is given in (9). Here, however, lunga is the V1 which makes the construction different from those given above in (1). Furthermore, these two predicates are separated by a pause and have the same intonation pattern as described above for (8). Therefore, the example does not classify as a multi-verb construction.

$\begin{array}{lll}\text { Tikus-é } & \text { lunga, } & \text { mlayu } \\ \text { mouse-DEF } & \text { go } & \text { run }\end{array}$

'The mouse goes away, runs.' (JAV-20160404-IJ-35-C-78M-frogstory)

\subsection{CAUSED MOTION}

For Caused motion, there are several examples of constructions in which the V2 expresses the Path, in this case lunga 'go (away)'. The combinations are limited, the only V1s of Caused motion found in this construction are gawa 'carry', as in (10), and surung 'push', as in (11) (usually occurring with prefix $d i-{ }^{\prime} U V^{\prime}$ to indicate that the undergoer is the grammatical subject). 


$\begin{array}{llllllll}\text { Bal } & \text { kuwi } & \text { mau } & \text { di-lebok-ké } & \text { kotak, banjur di-gawa lunga } \\ \text { ball } & \text { DEM } & \text { DEM } & \text { UV-enter-APPL box then UV-carry go }\end{array}$

'That ball is put in the box, and then taken away.' (JAV-20160331-IJ-40-C-23M-stories)

$\begin{array}{lll}\text { Terus } & \text { di-surung } & \text { lunga } \\ \text { then } & \text { UV-push } & \text { go }\end{array}$

'Then (she) is pushed away.' (JAV-20160404-IJ-22-C-40M-stories)

Another case is formed by the constructions in which lunga as V2 is combined with tinggal 'leave' as V1, as in (12).

Lading-é di-dèlèh uga, terus di-tinggal lunga
knife-DEF UV-put too then UV-leave go
'The knife is put down as well, and then is left behind.'
(JAV-20160403-IJ-48-C-54M-clips)

The combination ditinggal lunga 'uv-leave go' has been incorporated into the dictionary (Rob van Albada and Th. Pigeaud 2007: 1007) with the meaning 'to be left behind alone'. It can be argued that, in this case, lunga has a different function to that in the other combinations with a di-verb, since the act of 'going away' here does not refer to the undergoer, as in the other combinations, but to the agent of the clause (hence the two verbs do not have the same grammatical subject). This specific combination occurs nine times in the Indonesian corpus, and the variant ninggal lunga 'AV-leave go' and tinggal lunga 'leave go' occur five times, a total of fourteen times ( 0.17 per 1,000 words). The combinations digawa lunga 'uv-carry go' and disurung lunga 'uv-push go' occur six times $(0.07$ per 1,000 words) and one time ( 0.01 per 1,000 words), respectively. This means that more than half the occurrences of this construction in the Indonesian corpus consist of a fixed combination, which gives the impression that this construction is not very productive in Indonesian Javanese.

In the other cases in which Caused motion is expressed by a multi-verb construction, the V2 does not express the direction of movement, but rather the manner of movement, specifically of the causer. The two predicates seem to express two simultaneous events ("carrying while running", "pushing while running"), rather than having a dependency relationship, that is the one specifying the other (which is the case with directional V2s). See the examples (13)-(16), in which mlayu 'run' in (13)-(15) and mlaku 'walk' in (16) describe the manner of motion of the respective causers menjangan 'deer', wong 'person', bocah lanang loro 'two boys', and gajah 'elephant'. Therefore, I would propose classifying these examples as Accompanied motion, in which the cause and causer move together, rather than pure Caused motion, in which the causer does not necessarily undergo any movement. 
$\begin{array}{cccll}\text { (13) Terus bocah-é } & \text { di-gawa mlayu karo menjangan } \\ \text { then child-DEF } & \text { UV-carry } & \text { run with deer }\end{array}$

'Then the child is taken away running by the deer.'

(JAV-20160404-IJ-35-C-78M-frogstory) $\begin{array}{lllll}\text { (14) Kenap } & \text { di-jorog-ké } & \text { mlayu wong } & \text { ning undhak-undhak-an } \\ \text { table } & \text { UV-push-APPL run } & \text { person } & \text { LOC } & \text { stairs-RED-AN }\end{array}$

'The table is pushed away by someone running on the stairs.' (JAV20160404-IJ-35-C-78M-focuspictures)

(15) Terus ana bocah lanang loro ng-gawa mlayu bal-é kuwi then EXIST child male two AV-carry run bal-DEF DEM

'Then there are two boys who take away that ball running.' (JAV-20160402-IJ-39-C-17F-stories)

Kranjang-é mlaku, di-gawa mlaku gajah
basket-DEF walk UV-carry walk elephant
'The basket walks, it is carried walking by the elephant.'
(JAV-20160331-IJ-49-C-55F-stories)

The distinction between Accompanied motion and pure Caused motion is that, in Accompanied motion, both arguments move along the same path, while in Caused motion, the initiator (causer) is only the cause of another argument's (mover or causee) motion on a path (Xiaorong Xia 2017: 281). The first category comprises verbs of continuous causation of accompanied motion (for example, "take", "bring"), whereas the second refers to verbs of instantaneous causation of ballistic motion (for example, "throw", "poke", "slap") (Adele E. Goldberg 1995: 126 following S. Pinker 1989). These verbs are claimed to have different syntactic frames, and it is therefore relevant to distinguish them.

Multi-verb constructions expressing motion events in Indonesian Javanese are possible, but not frequent in this corpus. Manner of motion verbs can combine with Path verbs to form a complex predicate, but these combinations are limited and infrequent. No combination has been found in which lunga meets the requirement of functioning as a Path verb in V2 position, which is to have a mono-clausal intonation pattern with no pause. When multi-verb constructions occur to encode Caused motion, the V2 usually refers to the motion of the causer: it expresses either the path of motion of the causer (as in ditinggal lunga) or the manner of motion of the causer (V2 mlaku or mlayu). In the latter case, the construction expresses Accompanied motion rather than pure Caused motion.

\section{Multi-Verb motion constructions in SRAnANTONGO}

In this section, I give an overview of the multi-verb constructions encoding motion which were found in the Sranantongo corpus. I again focus on two sub-types: the first one expressing Manner of motion; the second one Caused motion. 
Sranantongo is commonly described as having a wide range of serial verb constructions (which I take to be the equivalent of multi-verb constructions) and is said to express a whole range of meanings with these constructions. The working definition used in Bert Jansen, Hilda Koopman, and Pieter Muysken (1978: 125) states that serial or multi-verb constructions are those constructions which contain more than one verb, usually one "lexical" and one more "grammatical" verb, and only one overt subject. Constructions which are excluded from this definition are those that contain overt conjunctions or complementizers, in which one of the verbs serves as an auxiliary or modal auxiliary to the other verb, and those in which one of the verbs serves as an infinitive complement to the other verb. A possible explanation for the abundance of multi-verb constructions could be the small lexicon of and general lack of word-deriving morphemes in Sranan (Mark Sebba 1984). Since George L. Huttar (1975), it has also been stressed that West-African languages have been instrumental in the genesis of serial verb constructions in the Surinamese creoles. See Pieter Muysken and Norval Smith (2014) for further discussion.

One of the multi-verb constructions characteristic of Sranantongo is the directional multi-verb construction, as in (17), in which the V2 (komoto 'come.out') indicates the direction (Yakpo 2017: 69; Kofi Yakpo and Adrienne Bruyn 2015: 150)

$$
\begin{array}{lllllllll}
M i & \text { teki } & \text { a } & \text { moni } & \text { komoto } & \text { na } & \text { (ini) } & \text { a } & \text { dosu } \\
\text { 1SG } & \text { take } & \text { DEF } & \text { money } & \text { come.out } & \text { LOC } & \text { inside } & \text { DEF } & \text { box }
\end{array}
$$

'I took the money out of the box.' (Yakpo and Bruyn 2015: 151)

In the next paragraphs, I discuss the motion multi-verb constructions which occur in the Sranantongo data.

\subsection{MANNER OF MOTION}

Below are some examples of the first category of motion events, mainly expressing the manner of motion events, found in the Sranan corpus. These concern combinations in which the V1 expresses the Manner of motion, while the V2 expresses the Path of motion. The combinations are, for example, waka komopo 'walk come.from' in (18), lon komopo 'run come.from' in (19), lon go and lon gwe 'run go' in (20) and (21), and waka gwe 'walk go' in (22).

$$
\begin{array}{lllllll}
\text { A } & \text { man } & \text { waka } & \text { komopo } & \text { uit } & \text { a } & \text { oso } \\
\text { DEF } & \text { man } & \text { walk } & \text { come.from } & \text { out } & \text { DEF } & \text { house }
\end{array}
$$

‘The man walks out of the house.' (JVN-20170406-SJ-47-301-59M-clips-sr)

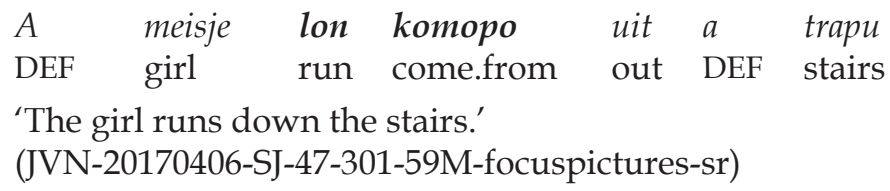


(20) A dagu lon go in' a busi

DEF dog run go in DEF forest

'The dog runs into the forest.' (JVN-20170406-SJ-47-301-59M-frogstory-sr)

(21) Dan a boi $E$ lon $f_{-} e$ lon gwe fu a owrukuku then DEF boy PROG run $f_{-}$PROG run go for DEF owl

'Then the boy runs $f_{-}$, runs away from the owl.'

(JVN-20170410-SJ-42-501-21F-frogstory-sr)

$\begin{array}{llll}\text { (22) } & \text { A } & e & \text { waka } \\ \text { DEF } & \text { PROG } \\ & \text { walk go }\end{array}$

'He is walking away.' (JVN-20170407-SJ-45-401-31F-stories-sr)

The fact that the combination of lon 'run' and gwe 'go' is very common among Sranan speakers is confirmed by the self-repair observed in (21): it seems as if the speaker wants to begin uttering the prepositional phrase fu a owrukuku 'from DEF owl' directly after the verb lon, but then self-repairs to add gwe, probably because she considers it more correct.

As can be seen in these examples, the meaning 'to go' is expressed by two verbs in Sranan: go and gwe. The difference between these two verbs is that go usually occurs in combination with a Goal (location) as in (20) and (23), whereas gwe usually occurs without any following argument and has a more deictic meaning of 'go away'. It is therefore the most similar to the Surinamese Javanese combination mlayu lunga, which also has a deictic meaning and does not usually have a Goal argument.

$\begin{array}{lllll}\text { (23) } & \text { waka } & \text { go } & \text { na } & \text { busi } \\ \text { PROG } & \text { walk } & \text { go } & \text { LOC } & \text { forest }\end{array}$

'He walks to the forest.' (JVN-20170407-SJ-45-401-31F-frogstory-sr)

Other Manner of motion-verbs found as V1s in multi-verb constructions with gwe in the corpus are frei 'fly' and dyompo 'jump'. As for the expression of "direction towards", Jansen, Koopman, and Muysken (1978: 140) argue that Sranantongo can express this in a construction with kon 'come' as a V2, as in (24), where kon has only an inherent locative deictic meaning without a Goal argument following it.

$\begin{array}{llll}\text { (24) } & \text { A } & \text { waka } & \text { kon } \\ \text { DEF } & \text { PROG } & \text { walk } & \text { come }\end{array}$

'She comes walking.' (Jansen, Koopman, and Muysken 1978: 141)

In the corpus collected for this study, there are no occurrences of a multi-verb construction with kon as V2. However, I did find some sentences with kon as a V2 in multi-verb constructions in the corpus of Kofi Yakpo and Stanley Hanenberg (2011), such as combinations with motion verbs as waka 'walk' in (25) and fadon 'fall' in (26), the latter also with a Goal argument. 
(25) A e waka go waka kon

DEF PROG walk go walk come

'He is walking back and forth.' (SRA11cor-e1)

(26) Wan san' fadon kon a gron

INDF thing fall come DEF ground

'Something falls to the ground.' (SRA11cor-e1)

These constructions are not infrequent in these additional data, so they are definitely part of the Sranan repertoire, but somehow did not show up in my own (admittedly limited) corpus. This could also be a particular characteristic of these speakers, since all the speakers in my corpus were Javanese speakers, possibly with a different competence in Sranan than the speakers interviewed by Yakpo and Hanenberg, but this question remains open to investigation.

\subsection{CAUSED MOTION}

The second category concerns constructions which express Caused motion with "direction away". Here the V1 is a transitive verb followed by the object, which then becomes the subject of V2 gwe as in (27). The transitive verbs used as V1 in this category are verbs expressing caused motion such as trowe 'throw', pusu 'push', and bonk 'throw'; see (28). This type of construction occurred seven times in the corpus (0.9 times per 1,000 words).

(27) A tyar a boi gwe

DEF carry DEF boy go.away

'He carries the boy away.' (JVN-20170407-SJ-45-401-31F-frogstory-sr)

(28) Wan man pus' a mèisye komopo uit a tafra

INDF man push DEF girl come.from out DEF table

'A man pushes the girl from the table.'

(JVN-20170406-SJ-47-301-59M-focuspictures-sr)

In the supplementary corpus of Yakpo and Hanenberg (2011), I also found occurrences of Caused motion with "direction towards", in which a verb of Caused motion as V1 is combined with kon in V2, as in (29).

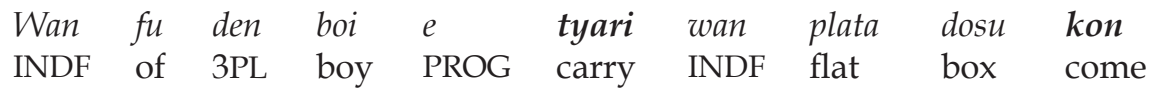

'One of the boys is carrying a flat box (towards the scene).' (SRA11ger-ke)

In Sranantongo, multi-verb motion constructions expressing "direction away" are formed with V2 gwe, with both Manner of motion and Caused motion constructions. The latter constructions have the object in a position between V1 and the particle. Sranantongo also has the possibility to express 'direction towards' in a multi-verb motion construction, with V2 kon. 


\section{Motion constructions in Dutch}

This section describes the constructions found in the Dutch corpus expressing the same types of events as described in the previous paragraphs.

\subsection{MANNER OF MOTION}

Dutch does not employ multi-verb constructions to express motion events. Manner of motion events similar to the ones above are usually encoded by means of a special kind of compound verb, referred to as "particle verb" (Geert Booij 2007: 186) or "separable verb" (W. Haeseryn et al. 1997: 12.2.2.1), such as wegrennen 'run away' or binnengaan 'go into'. The essential characteristic of this type of verb, comparable to English phrasal verbs such as look up, is that it consists of two parts, which form one unit in the infinitive, but can be separated in certain cases (Booij 2007: 22). This separation happens when the verb is conjugated as in (30) or in the case of an infinitive with te 'to' or participle with prefix ge-: opbellen 'call' > op te bellen 'to call', opgebeld 'call.PRTC'.

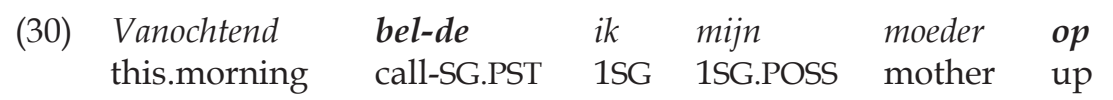

'This morning I called my mother.' (Karin van Usen et al. 2012: 104)

Examples from the Surinamese Dutch corpus, with the particle verb of movement wegrennen 'run away' and wegvliegen 'fly away', are given in (31) and (32). In both of these examples, the particle weg 'away' which expresses Path, follows the main verb expressing Manner rent 'run.3sG' or vliegen 'fly', although not completely separated from it by an intervening element as in the examples above. This order, which differs from the one in the infinitive (wegrennen), shows the independent behaviour of these two elements.

$\begin{array}{llll}\text { En } & \text { hij } & \text { ren-t } & \text { weg } \\ \text { and } & \text { he } & \text { run-3SG } & \text { away }\end{array}$

'And he runs away.' (JVN-20170329-SJ-09-400-63F-stories-nl)

$\begin{array}{llll}\text { Alle wespen } & \text { vlieg-en weg } \\ \text { all wasps fly-3PL } & \text { away }\end{array}$

All wasps fly away.' (JVN-20170329-SJ-09-400-63F-frogstory-nl)

The similarity in linear order to the Sranan construction lon gwe when the verb occurs in second position in main clauses is essential here: the Manner of motion verb occurs first, followed by the path, in this case a particle. Theoretically speaking, speakers could have also produced or encountered sentences in which the verb and particle are not separated, for example, when they are preceded by a modal verb: hij wil wegrennen 'he wants to run away'. However, all forms of this verb type occurring in the corpus are conjugated and hence separated. This type of construction, movement verb + weg, occurs nine times in the corpus (1.5 times per 1,000 words). The verbs which are used are rennen 'run', lopen 'walk', vliegen 'fly', springen 'jump', and vluchten 'flee'. 


\subsection{CAUSED MOTION}

In the corpus, Caused motion expressing "direction away" can be encoded by the same construction as Manner of motion: the combination of a verb (in this case transitive) + particle weg, which are usually then separated by the object. Example (33) shows a sentence in which the main verb stoot 'push' is transitive and is separated from the particle weg by the object die doos 'that box'.

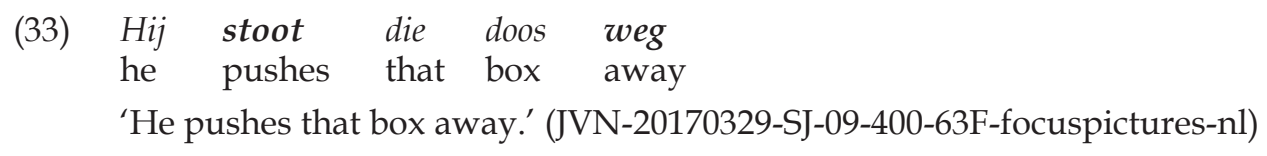

The construction with an object and transitive verb + weg (either together as an infinitive or past participle or separated by the object) occurs sixteen times in the corpus (2.7 times per 1,000 words). The transitive verbs used as V1 are halen 'take', gooien 'throw', schoppen 'kick', stoten/duwen 'push', and brengen 'carry'. All of these occurrences have the order verb-object-particle weg.

In Dutch, motion constructions expressing "direction away" are not multiverb constructions but formed by using particle weg, both with Manner of motion and Caused motion constructions. The latter constructions have the object in a position between V1 and V2.

\section{Directionals in Surinamese Javanese \\ 6.1 MANNER OF MOTION}

As described above, in Section 7 Surinamese Javanese speakers can express Manner + Path by means of a multi-verb construction, in which the V2 expresses the Path. Constructions with lunga 'go away' as the V2 in a multiverb construction are abundant in the Surinamese Javanese data, but much less prevalent in the Indonesian data. In the Surinamese corpus, this construction of Manner verb + lunga occurs seventy-five times (0.9 time per 1,000 words), against zero occurrences in the Indonesian corpus.

The verbs used as V1s are usually Javanese Manner of motion verbs such as mlayu 'run', mlaku 'walk', mencolot 'jump', mrobos 'crawl', mabur 'fly'; however, there is also one case in which lunga is combined with the Dutch verb sluipen 'sneak'. Interestingly, this is almost the exact same set of verbs which is used in constructions with gwe in Sranantongo (Section 4.1) and with weg in Dutch (Section 5.1).

The case of mlayu lunga 'run go.away' deserves special attention. It is the most frequent of all multi-verb constructions with lunga in the Surinamese corpus (forty-three occurrences, 0.5 per 1,000 words), whereas it does not occur at all in the Indonesian corpus. Discussions with Indonesian speakers showed that, as a combination, mlayu lunga is not considered ungrammatical. However, it is does not sounds very natural very natural to Indonesian speakers, because mlayu and lunga both already carry some inherent locative deictic meaning of 'off/away' and combining them could be superfluous in this sense. This is confirmed by Stuart Robson and Singgih Wibisono's dictionary of Javanese 
(2002: 578), which gives 'to run (off, away)' as the gloss for mlayu and 'to go (away, out)' for lunga (2002: 456). In Vruggink's dictionary of Surinamese Javanese, the first meaning of mlayu is 'to run, to jog', whereas 'to flee, to run (away)' is given as the second meaning. This could indicate a slight shift in the meaning of mlayu in Suriname, in which it is less deictic and interpreted more purely as a manner of motion. The verb lunga is glossed as 'go, go away'.

\subsection{CAUSED MOTION}

Verbs in the second category are transitive verbs marked with the $d i$-prefix (undergoer voice). These are, for example, disurung 'to be pushed', digawa 'to be carried', dijongkrokké 'to be pushed from behind', and disépak 'to be kicked'. This set is also very similar to those used in constructions with Caused motion verbs + gwe in Sranan (Section 4.2) and Caused motion verbs + weg in Dutch (Section 5.2). As can be seen in Table 2, these constructions are more frequent in the Surinamese data than in the Indonesian corpus.

\begin{tabular}{lll}
\hline & Surinamese Javanese & Indonesian Javanese \\
\hline di-verb + lunga & $25(0.31 / 1,000$ words $)$ & $16(0.19 / 1,000$ words $)$ \\
N-verb + lunga & $4(0.05 / 1,000$ words $)$ & $1(0.01 / 1,000$ words $)$ \\
ø-verb + lunga & 0 & $4(0.05 / 1,000$ words $)$ \\
\hline
\end{tabular}

Table 2. Overview of Caused motion + lunga constructions in the Javanese corpora (occurrences/1000 words).

The combination digawa lunga 'uv-carry go.away' is frequently encountered and can be argued to be a fixed expression for "carrying something away" (confirmed by Indonesian informants). In all cases of di-verb + lunga in the Indonesian corpus, it can be argued that lunga refers to the motion of the actor and not of the undergoer. This brings us to a second distinguishing point between the Surinamese and Indonesian speakers: Accompanied versus Caused Motion.

Whereas in the Indonesian data, all cases of di-verb + lunga express a kind of Accompanied motion (that is, both the actor and the undergoer follow the same path of motion), in the Surinamese data there are quite a few cases of Caused motion (that is, the movement of the undergoer/causee is caused by the actor/causer, who does not follow the same path of motion). This is clear in combinations such as disépak lunga 'uv-kick go.away' or dijongkrokké lunga 'Uv-push.over go.away', in which the undergoer is the only argument which actually moves away, since the actor (the person kicking or pushing) remains in one place.

\subsection{OTHER CASES}

As was described in Section 4, apart from the construction of verb + 'go' for direction away, Sranan also has the possibility to express "direction towards" 
with a multi-verb construction, using V2 kon 'come'. The question is whether a similar construction can appear in either Surinamese or Indonesian Javanese.

Both the Surinamese Javanese and Indonesian Javanese corpora include quite a few occurrences of verbs of movement followed by teka, which can mean 'come/arrive'. However, in most of these cases, teka is used with a prepositional meaning to indicate the Source of movement, as in (34). In these cases, it is basically a dialectal variant of seka/saka 'from, out of', which is different from the verb teka 'come' (see the two different dictionary entries in Robson and Wibisono 2002).

$$
\begin{aligned}
& \text { metu teka omah } \\
& \text { go.out from house } \\
& \text { 'go out from/exit the house' (JAV-20160420-IJ-27-E-56F-clips) }
\end{aligned}
$$

Cases in which teka is combined with the Source are common in both Surinamese and Indonesian Javanese, but it should be noted that they are only found among speakers of the East-Javanese dialect in the Indonesian corpus (which is congruent with the fact that Robson and Wibisono describe this usage of teka with the meaning 'from, out of' as dialectal). The fact that teka behaves more like a preposition in these cases becomes clear in the following example, in which there is no indication of movement at all but, instead, teka just expresses the point from which the bird is looking:

$$
\begin{array}{lllll}
\text { Manuk-é } & \text { darès } & n \text {-delok-ké } & \text { teka wit liya-né } \\
\text { bird-DEF } & \text { owl } & \text { AV-look-APPL from tree other-DEF }
\end{array}
$$

'The owl is watching him from the other tree.'

(JVN-20140512-SJ-01-200-83M-frogstory)

This makes the construction obviously different from that with kon as V2 in Sranantongo, which is used to indicate Goal and not Source in a multi-verb construction (Jansen, Koopman, and Muysken 1978: 140). However, there are a few cases in which teka is used without a location following it, all of which occur in the Surinamese corpus. In these cases, it has only an inherent locative deictic meaning (of movement towards the scene). The movement verbs which are combined with teka to form an inherent locative deictic construction are mlayu 'run' and mlaku' walk'. These verbs are also the most frequent in deictic constructions with lunga 'go away' (see 6.1). See the examples (36) and (37). According to my informants, this deictic motion construction with V2 teka to express 'direction towards' is not possible in Indonesian Javanese. It occurs a total of six times in the Surinamese corpus ( 0.07 times per 1,000 words).

(36) Tyah lanang-é mlayu teka child male-DEF run come

'The boy comes running.' (JVN-20170324-SJ-43-401-37F-focuspictures) 
(37)

$\begin{array}{lll}\text { Tikus-é } & \text { mlaku } & \text { teka } \\ \text { mouse-DEF } & \text { walk } & \text { come }\end{array}$

'The mouse comes walking.' (JVN-20170324-SJ-43-401-37F-stories)

\section{Discussion}

Comparing multi-verb motion constructions in Surinamese and Indonesian Javanese brings several differences to light. First of all, there is a difference in frequency: constructions with lunga as a V2 expressing "direction away" are more frequent in Surinamese Javanese, both with Manner of motion and Caused motion verbs as V1. It is noteworthy that the combination of Manner of motion + lunga seems to occur particularly often in Surinamese Javanese, but not at all in Indonesian Javanese. I would claim that this difference can be explained by cross-linguistic transfer from Sranantongo, in which the construction Manner/Caused motion verb + 'go' is also very frequent to express "direction away". Since Surinamese Javanese speakers have been in contact with Sranantongo for a long period of time (since the beginning of migration), they will have encountered this combination many times. By frequently hearing and producing it while speaking Sranantongo, heritage speakers will transfer it into their heritage language as well. This change can be classified as a pattern change: speakers copy "the organization, distribution, and mapping of grammatical or semantic meaning" without the phonological form itself, a process also referred to as calquing, grammatical replication or relexification (Yaron Matras and Jeanette Sakel 2007; Yakpo and Muysken 2014). In this case, the Javanese speakers copy the (frequency) distribution as well as the mapping of semantic meaning from Sranantongo, which is how this construction has become so frequent and common in Surinamese Javanese.

Secondly, there is the extension of the usage contexts: V2 lunga is combined with a wider range of V1s in Surinamese Javanese than in Indonesian Javanese, in which it is restricted to V1 surung 'push', gawa 'carry', and a fixed expression with tinggal 'leave'. This is a form of semantic extension which can be classified as the first stage of contact-induced grammaticalization (Bernd Heine and Tania Kuteva 2005: 80). In this case, heritage speakers analyse a grammatical element differently from baseline speakers: hence here lunga is analysed as an element expressing direction or Path of motion only, and not Manner. This, I would say is caused by entrenchment, derived from both Sranantongo and Dutch: in both of these languages, the schema Manner/Caused motion verb + 'go'/'away' is very frequent. The particularity of this construction is that the direction/path of motion is encoded in a separate element; either a verb or a particle. Because of the frequency and recency of encountering this schema in both contact languages, it will become more entrenched in the mind of the multilingual heritage speaker, and hence also more natural and frequent in their heritage language. This leads to the preference of Surinamese speakers to "split up" the notion of path from the motion verb itself, while Indonesian speakers use one single verb to express both aspects of the meaning. The main source language of this construction in Surinamese Javanese is Sranantongo 
rather than Dutch, because of both the greater time depth of contact and the structural similarity (both lunga and gwe are verbs with a similar syntactic behaviour). However, the schema of expressing "direction away" by means of a separate element is further entrenched and reinforced by the existence of the particle construction in Dutch.

The third difference is in its meaning: whereas the constructions in Indonesian Javanese usually describe either the Manner of motion of the causer in a Manner of motion construction, or Accompanied motion in the Caused motion construction, in the Surinamese constructions the V2 lunga always refers to the movement of the causee, or the undergoer of the movement, even without referring to the motion of the causer. This is also similar to the constructions in Sranantongo and Dutch; here the V2 gwe or particle weg also refers to the motion of the causee rather than the causer. This is also a case of pattern replication, in this case of the semantics of this particular element.

One preliminary, but promising observation was that, in Surinamese Javanese, not only "direction away" but also "direction towards" can be expressed by a multi-verb construction. This is probably also attributable to cross-linguistic transfer from Sranantongo, which has the possibility to express "direction towards" in a multi-verb construction with V2 kon. The Surinamese Javanese speakers might then replicate this construction in their heritage language, by using the verb teka 'come'. The possibility for this new construction is offered by the fact that the preposition teka 'from, out of' can be in the same syntactic position (post-verbal), which reduces the step towards using teka 'come' in that same position.

One thing we do not see in Surinamese Javanese, as opposed to Sranantongo and Dutch, is the intervention of the object in between the Caused motion verb and the deictic element, such as pus' en gwe 'push him away'. Possibly, this is because in Javanese the two verbs still form a stronger unit than do the verbs in Sranan, or the verb + particle in Dutch, and that this is such a strong syntactic feature which does not change easily. Therefore, syntactic constraints still apply: as a starting point for linguistic change, there has to be a free, possible slot offered by the heritage language structure.

\section{CONCLUSION}

In this article, I have aimed to answer the question of whether the multiverb motion constructions expressing "direction away" in Sranantongo and Surinamese Javanese are related. Has there been some form of cross-linguistic transfer from Sranan to Surinamese Javanese, manifest in frequency possible combinations? These questions should be answered affirmatively: the multiverb motion construction has become more frequent and has spread to more possible combinations, mostly under the influence of the Sranan multiverb motion construction. It has been reinforced by the Dutch particle verb construction. These constructions share the fact that the direction is expressed by an element separate from the verb, a schema which is then transferred into Surinamese Javanese through the mechanism of entrenchment. 
Questions for further research should investigate whether the construction has also spread to other verb pairs, as shown with the preliminary results about V2 teka, parallel to kon in Sranantongo. It could even look beyond the realm of motion constructions and examine other multi-verb constructions, as these are very frequent in Sranantongo. A first pilot has shown that the direction of change in multi-verb constructions in Surinamese Javanese is not always from less to more multi-verb constructions, but depends on the grammar of the contact language, in this case Sranantongo: whereas Indonesian Javanese uses multi-verb constructions to express instrumental relations (with V2 nganggo 'use'), Surinamese Javanese prefers the preposition karo 'with', parallel to Dutch and Sranan. Therefore, there is probably not a simple overall typological tendency towards more multi-verb constructions, but rather a series of highly constrained contact-induced change phenomena which require specific syntactic possibilities a priori in the target language as well as an entrenched structure in the source language.

ABBREVIATIONS

$\begin{array}{ll}\text { AN } & \text { Suffix -an } \\ \text { APPL } & \text { Applicative } \\ \text { AV } & \text { Actor voice } \\ \text { DEF } & \text { Definite } \\ \text { DEM } & \text { Demonstrative } \\ \text { EXCL } & \text { Exclamation } \\ \text { EXIST } & \text { Existential verb } \\ \text { FUT } & \text { Future } \\ \text { INDF } & \text { Indefinite } \\ \text { LOC } & \text { Locative } \\ \text { PL } & \text { Plural } \\ \text { POSS } & \text { Possessive } \\ \text { PRF } & \text { Perfect } \\ \text { PROG } & \text { Progressive } \\ \text { PST } & \text { Past tense } \\ \text { RED } & \text { Reduplication } \\ \text { REL } & \text { Relative pronoun } \\ \text { SG } & \text { Singular } \\ \text { UV } & \text { Undergoer voice }\end{array}$

BIBLIOGRAPHY

Albada, Rob van and Th. Pigeaud. 2007. Javaans-Nederlands woordenboek. Leiden: KITLV Press.

Booij, Geert. 2007. The grammar of words; An introduction to linguistic morphology. Oxford: Oxford University Press.

Goldberg, Adele E. 1995. Constructions; A construction grammar approach to argument structure. Chicago, IL: University of Chicago Press. 
Haeseryn, W., K. Romijn, G. Geerts, J. de Rooij, and M.C. van den Toorn. 1997. Algemene Nederlandse Spraakkunst. Second revised edition. Groningen/ Deurne: Martinus Nijhoff, Wolters Plantyn. [Retrieved from: http:/ / ans. ruhosting.nl/e-ans/; accessed on 21-5-2018.]

Heine, Bernd and Tania Kuteva. 2005. Language contact and grammatical change. Cambridge: Cambridge University Press.

Huttar, George L. 1975. "Sources of Creole semantic structures", Language 51(3): 684-695.

Irizarri van Suchtelen, Pablo. 2016. Spanish as a heritage language in the Netherlands; A cognitive linguistic exploration. PhD thesis, Radboud University Nijmegen. [Utrecht: LOT.]

Jansen, Bert, Hilda Koopman, and Pieter Muysken. 1978. "Serial verbs in the Creole languages", Amsterdam Creole Studies 2: 125-159.

Matras, Yaron and Jeanette Sakel. 2007. Grammatical borrowing in cross-linguistic perspective. Berlin: Mouton de Gruyter.

Mayer, Mercer. 1969. Frog, where are you? New York: Dial Press.

Muysken, Pieter and Norval Smith (eds). 2014. Surviving the Middle Passage; The West Africa-Surinam Sprachbund. Berlin: Mouton de Gruyter.

Onar Valk, Pelin and Ad Backus. 2013. "Syntactic change in an immigrant language; From non-finite to finite subordinate clauses in Turkish", Keeleteaduse, Eesti ja soome-ugri Linguistics, ajakiri. Journal of Estonian and Finno-Ugric 4(2): 7-29.

Pinker, Steven. 1989. Learnability and cognition; The acquisition of argument structure. Cambridge, MA: MIT Press.

Robson, Stuart and Singgih Wibisono. 2002. Javanese English dictionary. Hong Kong: Periplus Editions.

Schmid, Hans-Jörg. 2012. "Entrenchment, salience, and basic levels", in: Dirk Geeraerts and Hubert Cuyckens (eds), Oxford handbook of cognitive linguistics, pp. 117-138. Oxford: Oxford University Press.

Sebba, Mark. 1984. "Serial verbs; A boost for a small lexicon", Oso 3(1): 35-38.

Talmy, Leonard. 1985. "Lexicalization patterns; Semantic structure in lexical forms", in: Timothy Shopen (ed.), Language typology and syntactic descriptions. Vol. 3: Grammatical categories and the lexicon, pp. 57-149. Cambridge: Cambridge University Press.

Usen, Karin van, Walter Haeseryn, and Paula Fikkert. 2012. "Weet jij wanneer je op gaat splitsen? Onderzoek naar de voorkeur voor het bijeenhouden of splitsen van partikelwerkwoorden in de bijzin", Taal en Tongval 64(1): 103-128.

Villerius, Sophie. 2018. Development of Surinamese Javanese. PhD thesis, Radboud University Nijmegen. [Utrecht: LOT.]

Vruggink, Hein (in collaboration with Johan Sarmo). 2001. Surinaams-JavaansNederlands woordenboek. Leiden: KITLV Press.

Xia, Xiaorong. 2017. "Verb class-specific caused-motion constructions", Chinese Semiotic Studies 13(3): 269-287. [DOI:10.1515/css-2017-0016.] 
Yakpo, Kofi. 2017. "Creole in transition; Contact with Dutch and typological change in Sranan", in: Kofi Yakpo and Pieter Muysken (eds), Boundaries and bridges; Multilingual ecologies in the Guianas, pp. 57-86. Berlin: Mouton de Gruyter.

Yakpo, Kofi, Margot van den Berg, and Robert Borges. 2015. "On the linguistic consequences of language contact in Suriname; The case of convergence", in: Eithne B. Carlin et al. (eds), In and out of Suriname; Language, mobility, and identity, 154-195. Leiden: Brill. [DOI: 10.1163/9789004280120_009.]

Yakpo, Kofi and Adrienne Bruyn. 2015. "Trans-Atlantic patterns; The relexification of locative constructions in Sranan", in: Pieter Muysken and Norval Smith (eds.), Surviving the Middle Passage; The West Africa-Surinam Sprachbund, pp. 135-174. Berlin: Mouton de Gruyter.

Yakpo, Kofi and Pieter Muysken. 2014. "Language change in a multiple contact setting; The case of Sarnami (Suriname)", in: Isabelle Buchstaller, Anders Holmberg, and Mohammad Almoaily (eds), Pidgins and Creoles beyond Africa-Europe encounters, pp. 101-140. Amsterdam: John Benjamins. 